\title{
IMPLEMENTASI COST POWER METERING UNTUK APLIKASI SOLAR GRID HYBRID POWER SYSTEM
}

\author{
Ivany Sarief ${ }^{1}$, Ketut Abimanyu ${ }^{2}$ \\ Program Studi Teknik Elektro, Fakultas Teknik \\ Universitas Sangga Buana YPKP Bandung \\ ivansarief@gmail.com
}

\begin{abstract}
ABSTRAK
Kebutuhan listrik nasional 226 TWh lebih tidak dapat lagi dipenuhi oleh produsen listrik nasional yang hanya memiliki kapasitas terpasang $50 \mathrm{GW}$ lebih. Kekurangan ini dapat menjadi peluang untuk mendorong produksi energi diluar provider listrik PLN. Distributed Generation (DG) menjadi alternatif produksi listrik yang menguntungkan karena dapat diadakan swakelola dan dekat dengan konsumen listrik,sehingga transmission losses dapat diminimalkan. Salah satu DG yang cukup populer adalah Solar Cell yang merupakan energi terbarukan ramah lingkungan berbasiskan cahaya matahari. Residential Solar - Grid Hybrid Power System merupakan kombinasi penggunaan listrik PLN (Grid) dengan Solar Cell. Sumber daya listrik yang aktif merupakan salah satu dari PLN atau Solar Cell. Bila listrik dari PLN padam atau cahaya matahari tersedia maka solar cell akan aktif mensuplai listrik ke rumah. Penggunaan listrik akan dimonitor, dilog, dan diolah oleh sistem sehingga pengguna dapat mengetahui estimasi penghematan biaya aktual yang diperoleh dengan menggunakan solar cel terhadap listrik PLN. Diharapkan dengan adanya keuntungan rupiah yang diperoleh, penghuni residensial akan tertarik menggunakan sistem hibrid ini.
\end{abstract}

Kata Kunci: Solar Grid Hybrid, Power Metering, Estimasi Biaya, Monitoring, Distributed Generation

\section{PENDAHULUAN}

Kebutuhan listrik nasional 226 TWh (2015) lebih tidak dapat lagi dipenuhi oleh produsen listrik nasional yang hanya memiliki kapasitas terpasang $50 \mathrm{GW}$ lebih[1]. Kekurangan ini dapat menjadi peluang untuk mendorong produksi energi diluar provider listrik PLN. Distributed Generation (DG) menjadi alternatif produksi listrik yang menguntungkan karena dapat diadakan swakelola dan lokasinya dekat dengan konsumen listrik,sehingga transmission losses dapat diminimalkan[2]. Salah satu DG yang cukup populer adalah sel surya (Solar Cell) yang merupakan energi terbarukan ramah lingkungan berbasiskan cahaya matahari.

Masyarakat harus dimotivasi untuk menggunakan energi terbarukan lebih banyak dan sering. Masif dalam pengertian jumlah pengguna meningkat persentasenya dan penetrasinya ke semua lapisan. Sedang intensif bermakna menaikkan tingkat penggunaan bagi yang sudah menggunakan energi terbarukan ini. Dalam penelitian ini, energi surya dipilih sebagai sumber energi terbarukan karena sinar matahari tersedia melimpah di Indonesia berkat posisinya di khatulistiwa. Melimpah baik dalam lamanya matahari bersinar maupun intensitas sinarnya.

Energi ini dapat dimanfaatkan dalam bentuk panas untuk memanaskan air atau sebagai penghasil energi listrik. Ada dua metode yang umum digunakan untuk membangkitkan listrik yaitu concentrating plant dengan cara memusatkan sinar matahari dari deretan reflektor ke satu kolektor yang akan memanaskan boiler untuk menggerakkan turbin generator, sedang metode lain dengan menggunakan sel photovoltaik yang dikenal juga sebagi sel surya yang langsung mengkonversi sinar matahari menjadi listrik.

Konversi langsung dengan sel surya menjadi pilihan untuk pembangkit listrik bagi rumah tangga, kantor, tempat umum dan industri karena lebih praktis dan dapat dibangun dengan kapasitas kecil. Berbeda dengan concentrating plant yang lebih kompleks konstruksinya dan memang cocok untuk menjadi pembangkit listrik terpusat berkapasitas besar.

Solar - Grid Hybrid Power System 
merupakan kombinasi penggunaan listrik PLN (Grid) dengan sel surya. Sumber daya listrik yang aktif dapat berasal dari PLN atau sel surya. Bila sinar matahari tersedia maka sel surya akan aktif mensuplai listrik ke rumah menggantikan listrik PLN. Penggunaan listrik akan dimonitor, direkam (log), dan diolah oleh sistem sehingga pengguna dapat mengetahui estimasi penghematan biaya aktual yang diperoleh dengan menggunakan solar cel terhadap listrik PLN. Diharapkan dengan adanya keuntungan rupiah yang diperoleh, masyarakat akan tertarik menggunakan sistem hibrid ini.

\section{PERMASAlahan}

Permasalahan yang diangkat dalam penelitian adalah bagaimana mempopulerkan penggunaan sel surya di Indonesia sehingga dapat membantu meningkatkan elektrifikasi masyarakat dan mengurangi penggunaan bahan bakar fosil pada pembangkit listrik.

Bagi masyarakat umum, perlu ditunjukkan keuntungan nyata yang diperoleh dalam menggunakan energi surya. Untuk masyarakat yang belum mendapat aliran listrik, jelas dengan adanya panel surya mereka dapat merasakan manfaat listrik dari energi alternatif ini. Lain lagi bagi masyarakat yang sudah dialiri listrik, tapi sering mengalami pemadaman. Adanya panel surya membantu kontinuitas ketersediaan listrik untuk peralatan listrik yang sedang beroperasi. Lalu bagaimana dengan masyarakat yang pasokan listriknya stabil. Apakah mereka tidak membutuhkan panel surya? Sudah diketahui bahwa cadangan energi fosil dunia terus menipis,sedang penggunaan energi global berbanding terbalik ,terus bertambah. Indonesia juga mengalami hal yang sama, sehingga penggunaan energi terbarukan di masyarakat harus diakselerasi.

Untuk menstimulasi penggunaan energi terbarukan khususnya panel surya, masyarakat akan diberi ilustrasi berapa rupiah yang berhasil dihemat dari penggunaan listrik dari panel surya. Diharapkan setelah mengetahui jumlah rupiah yang berhasil dihemat dalam 1 hari, 1 minggu, 1 bulan hingga 1 tahun, besaran rupiah yang signifikan akan membuktikan bahwa investasi panel surya memang menguntungkan dan pada gilirannya mereka akan menambah kapasitas panel surya serta menjadi contoh bagi masyarakat yang belum menggunakan panel surya untuk memulai penggunaan panel surya.
Berdasarkan permasalahan yang ada, dalam penelitian ini akan dilakukan beberapa tahapan penelitian yaitu pembuatan solar home sytem, pembuatan Purwarupa perangkat metering, dan integrasi Purwarupa sistem menjadi Solar Grid Hybrid Power System lengkap

\section{SOLAR GRID HYBRID POWER SYSTEM}

\subsection{Distributed Generation (DG)}

Distributed Generation (DG) dapat didefinisikan sebagai pembangkitan daya listrik di dalam jaringan distribusi atau berada di jaringan sisi pelanggan[2]. Dalam penjelasan lain, pengertian lebih luas DG merujuk ke pembangkitan daya di titik penggunaan listrik. Pembangkitan daya on-site di lokasi kebutuhan daripada dilakukan secara terpusat sehingga menghilangkan biaya, kompleksitas, ketergantungan, dan inefisiensi yang terkait dengan transmisi dan distribusi[2]. Seperti distributed computing dan distributed telephony, distributed generation menggeser kendali ke pengguna daya listrik.

Pada awalnya, distributed generation berupa generator combustion (seperti genset diesel) dimana generator tsb ekonomis dan umumnya andal, namun berpolusi. Sedangkan orang umumnya bertoleransi bila menggunakan pembangkitan berpolusi jika lokasinya jauh dari mereka, tapi akan berpikir dua kali bila diletakkan di luar jendela kamar atau pintu kantor.

Akhir akhir ini, sel surya menjadi pilihan DG yang populer. Walaupun outputnya bersih tapi intermittent sehingga menjadi strategi energi yang tidak lengkap untuk bisnis dimana energi dibutuhkan terus menerus, termasuk pada saat matahari tidak bersinar.

\subsection{Sistem Photovoltaik (PV)}

Teknologi sel surya langsung mengubah cahaya menjadi energi listrik. Modul Photovoltaik (PV) membuat listrik dari sinar matahari dan dengan sederhana, efektif, dan tahan lama. Diletakkan di bawah sinar matahari, tanpa part yang bergerak, dapat menjalankan peralatan listrik rumah tangga, mengisi baterai, atau menghasilkan energi untuk grid listrik.

$P V$ array adalah pengumpul energi yang merupakan generator matahari yang bekerja dengan efek photovoltaik. Ditemukan pada tahun 1839 oleh fisikawan Perancis Alexandre- 
Edmund Becquerel, efek photovoltaik menjelaskan bagaimana sel PV menghasilkan listrik dari energi yang berasal dari foton sinar matahari. Ketika sinar tsb mengenai sel PV, sel akan menyerap sebagian foton dan energi foton tsb ditransfer ke elektron di material semikonduktor. Dengan energi yang berasal dari foton, elektron dapat melepaskan diri dari posisi normalnya di dalam atom semikonduktor untuk menjadi bagian arus dalam rangkaian elektrik.

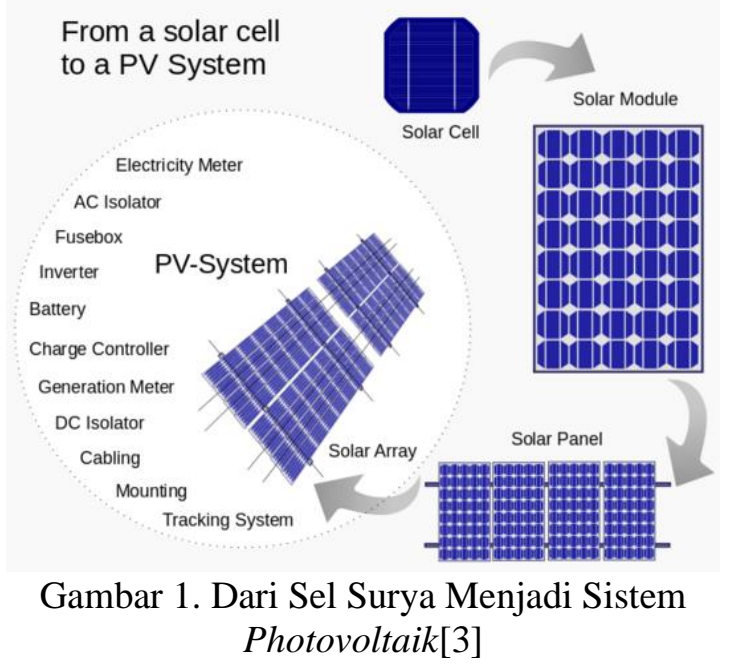

Kebanyakan sel PV termasuk ke salah satu dari dua kategori: crystalline silicon atau thinfilm. Module crystalline silicon dapat berupa monocrystalline, multicrystalline (poly), atau ribbon silicon. Thin film menunjukkan istilah yang meliputi beberapa teknologi berbeda, seperti amorphous silicon, dan host dari variasi yang menggunakan semikonduktor lain seperti cadmium telluride atau CIGS (Copper Indium Gallium Selenide). Teknologi thin film menghasilkan banyak diskusi penelitian dan merupakan pengembangan terkini, tetapi modul crystalline kini menguasai $80 \%$ marketplace global.

Untuk menggunakan energi dari array sel surya diperlukan beberapa komponen lain seperti inverter, charge controller, dan baterai untuk menjadi satu sistem elektrik surya. Komponen komponen yang dibutuhkan tergantung dari tipe sistem yang dirancang. Tipe tipe sistem tsb adalah [4]

\subsubsection{Sistem PV Direct}

Merupakan sistem elektrik surya paling sederhana yang terdiri dari jumlah komponen paling sedikit, biasanya hanya terdiri dari $P V$ array dan beban. Karena tidak menggunakan batere dan tidak terhubung ke grid listrik, energi listrik hanya diperoleh ketika matahari bersinar. Sistem ini hanya cocok untuk sedikit aplikasi seperti pompa air dan ventilasi; bila matahari bersinar, pompa atau fan dapat beroperasi.

\subsubsection{Sistem Off-Grid}

Walaupun sistem ini umum digunakan di lokasi terpencil tanpa layanan listrik, sistem ini dapat digunakan dimana saja. Beroperasi independen dari grid untuk menyediakan semua kebutuhan listrik rumah tangga. Sistem ini membutuhkan batere sebagai tempat menyimpan listrik untuk digunakan pada malam hari atau mendung, charge controller untuk melindungi batere dari overcharging, inverter untuk mengubah listrik DC dari photovoltaik menjadi AC untuk digunakan oleh peralatan listrik rumah tangga, dan semua alat yang dibutuhkan untuk memutuskan, memonitor, dan yang berkaitan dengan proteksi keselamatan.

\subsubsection{Sistem Grid-Tied dengan Batere}

Jenis ini serupa dengan sistem off-grid dari rancangan dan susunan komponennya, bedanya hanya sistem ini terhubung dengan grid listrik, sehingga mengurangi kebutuhan sistem untuk menyediakan listrik setiap saat.

\subsubsection{Sistem Grid-Tied Tanpa Batere}

Ini adalah sistem PV yang paling umum dan digunakan dalam penelitian ini, dimana dikenal juga sebagai on-grid, grid-tied, utilityinteractive, grid-intertied, atau grid-direct. Sistem ini menghasilkan listrik dan mengalirkan ke beban dan ke grid listrik. Komponen komponen sistem hanya terdiri dari array $\mathrm{PV}$, inverter, dan peralatan keselamatan listrik yang dibutuhkan (seperti fuses/breakers/pemutus/monitoring). Tidak terasa perbedaan antara sistem ini dengan hanya menggunakan listrik dari perusahaan listrik, kecuali sebagian atau seluruh energi listrik yang digunakan berasal dari matahari, sehingga tagihan listrik berkurang. Kerugian sistem tanpa batere ini adalah ketidakmampuannya menyediakan energi bila grid listrik padam.

\subsection{Electric Metering}

Meter listrik (electricity meter) atau meter energi (energy meter) adalah alat yag mengukur 
jumlah energi listrik yang digunakan oleh beban rumah, kantor, atau industri.umumnya alat ini dikalibrasi dalam unit billing, dimana kilowatt hour (kWh) biasa digunakan sebagai unitnya.

Peletakan alat untuk meng-capture informasi ini pada saat wiring sistem photovoltaik tergantung dari rekomendasi manufaktur sistem PV. Sebagai aturan umum, current transformer (CT) seharusnya dipasang pada sisi AC dari inverter sebelum dialirkan ke circuit breaker pada panel utama. CT ke dua juga diperlukan untuk memonitor beban net grid seperti yang ditunjukkan pada gambar berikut.

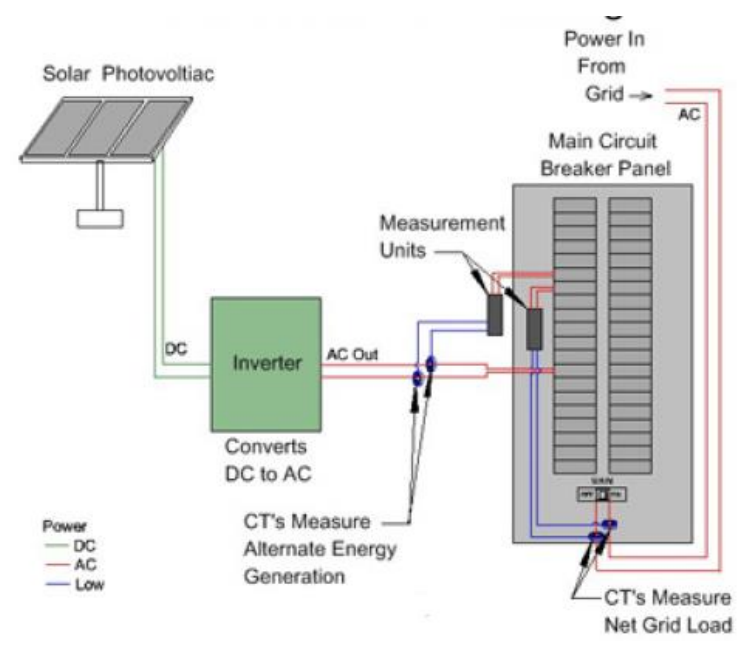

Gambar 2. Grid-Tied Inverter Metering [5]

\section{IMPLEMENTASI SISTEM}

\subsection{Analisa dan Perancangan}

Sasaran penelitian adalah rumah tinggal atau residensial yang menggunakan listrik satu fasa. Namun untuk uji laboratorium akan digunakan panel solar sel 2x $40 \mathrm{Wp}$ dengan beban rumah tangga sederhana. Sistem ini akan disebut sebagai solar home system (SHS) yang memiliki komponen komponen modul.

SHS akan digabung dengan grid PLN dimana pemilihan sumber listrik akan dilakukan manual dengan saklar. Jadi SHS adalah sumber listrik dengan energi matahari sedang grid PLN adalah sumber listrik dari distribusi PLN. Modul metering dengan fitur estimasi biaya daya terpakai akan diletakkan di jalur keluaran inverter yang menuju beban. Diagram Blok sistem dapat dilihat pada gambar 3.

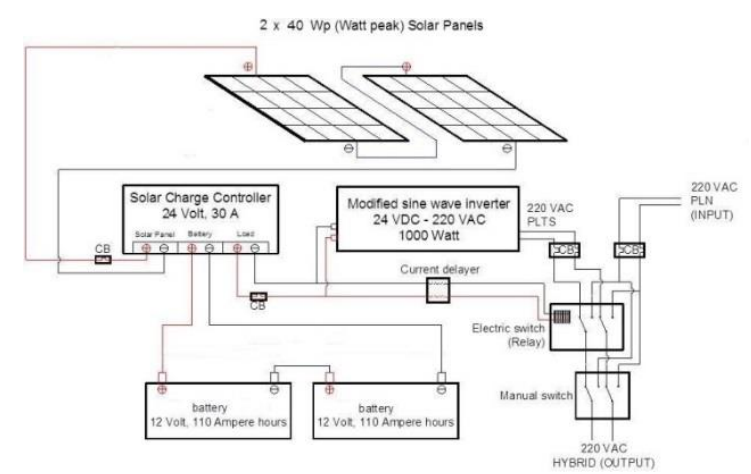

Gambar 3. Diagram Blok Solar Home System dengan Grid PLN

Modul cost power metering dibangun dari beberapa sub modul yaitu sub modul Arduino Uno R3 sebagai sub modul pengendali, sub modul LCD sebagai tampilan sistem, sub modul PZEM004 sebagai sub modul pegukur daya, dan sensor arus.

Rangkaian sub modul Arduino dapat dilihat pada gambar 4, sedang sub modul pengukur daya dan sub modul LCD dapat dilihat berturut turut pada gambar 5 dan 6 .

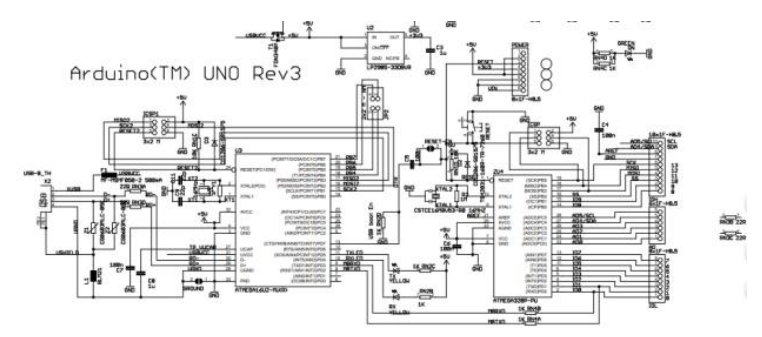

Gambar 4. Rangkaian Pengendali menggunakan Arduino

RANGE:U AC80-260V/50/60Hz

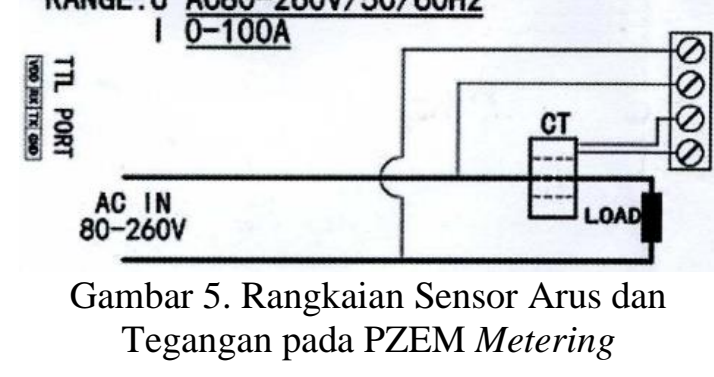




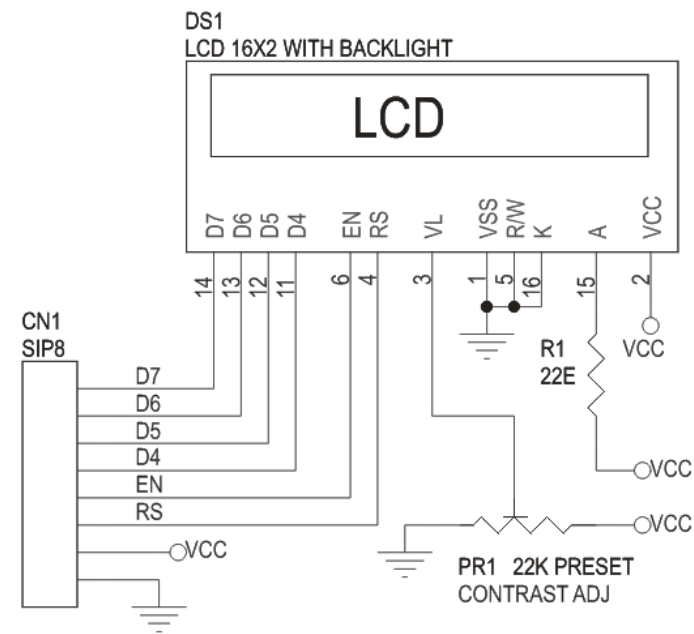

Gambar 7. Rangkaian Display LCD

\subsection{Implementasi dan Pengujian}

SHS yang dibangun memiliki modul panel surya, panel controller atau solar charge controller, Inverter, Batere, Box, dan Metering. Setiap modul memiliki spesifikasi sesuai dengan tabel berikut:

Tabel 1. Modul Modul SHS dan Spesifikasinya PV Module Panel Surya PV Modul Panel Surya $2 x$ 40WP

\begin{tabular}{ll} 
Solar Charge Controller & $30 \mathrm{~A} / 12$ volt - 24 volt \\
\hline Inverter & $\begin{array}{l}\text { Inverter DC 24V to AC } \\
220 \mathrm{~V} / 500 \mathrm{~W} \text { Pure Sine } \\
\text { Wave }\end{array}$ \\
\hline Battery & 110Ah 12V \\
\hline Panel Box & Plat Coating
\end{tabular}

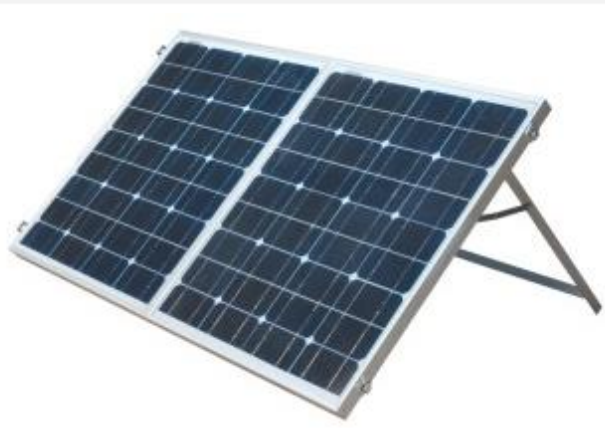

Gambar 8. Panel Surya

Implementasi untuk modul metering dapat dilihat pada gambar 8 yang menunjukkan purwarupa modul metering keseluruhan.

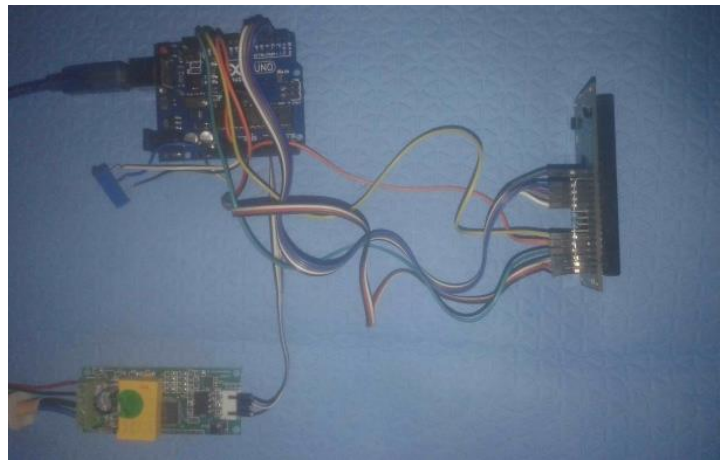

Gambar 8. Modul Sistem Monitoring dan Estimasi Biaya Daya Terpakai

Sedangkan implementasi sub modul kendali dengan menggunakan Arduino dapat dilihat pada gambar 9 .

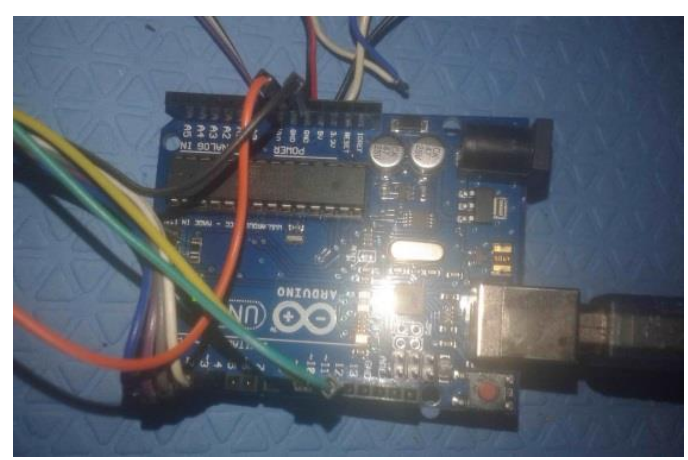

Gambar 9. Sub Modul Board Controller Arduino

Berikut gambar 10 menampilkan implementasi sub modul pengukur arus, tegangan, dan daya

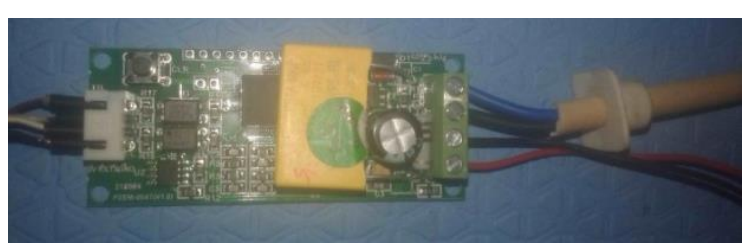

Gambar 10. Sub Modul Pengukur Tegangan, Arus, dan Daya

Sensor arus yang digunakan adalah jenis sensor arus full core (gambar 11) sehingga hanya cocok untuk penggunaan tetap dimana kawat penghantar yang diukur tetap, tidak berganti kawat. 


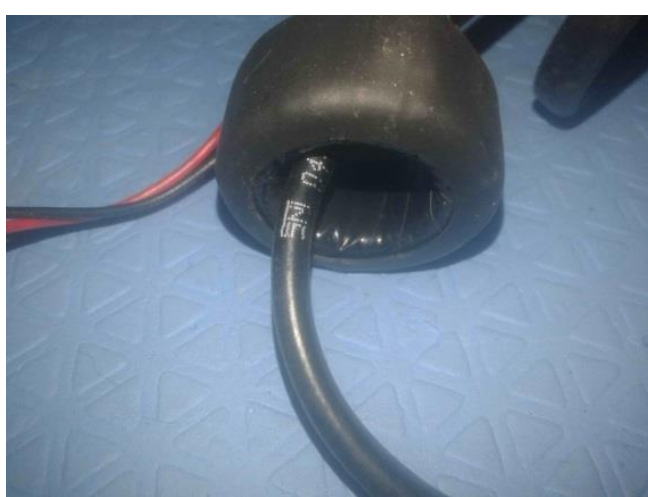

Gambar 11 Trafo Arus Full Core

Pada gambar 12, modul Liquid Crystal Display (LCD) digunakan sebagai tampilan sistem dengan kecerahan dan terang lampu latar (backlite) dapat diatur dengan variable resistor.

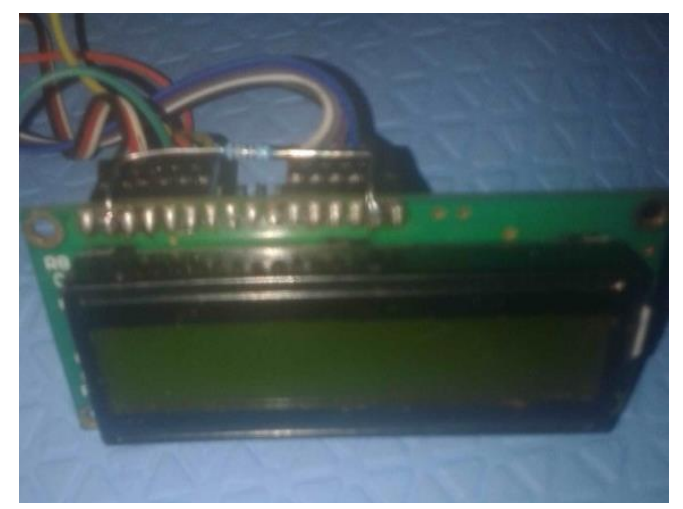

Gambar 12 Sub Modul Tampilan LCD

\section{HASIL DAN PEMBAHASAN}

Pengujian yang dilakukan di laboratorium elektronika adalah pengujian beban motor kipas angin seperti yang diperlihatkan gambar 13 . Akan diukur parameter dasar teganan dan arus yang digunakan beban kipas angin sebagai dasar perhitungan daya, energi dan biaya pemakaian.

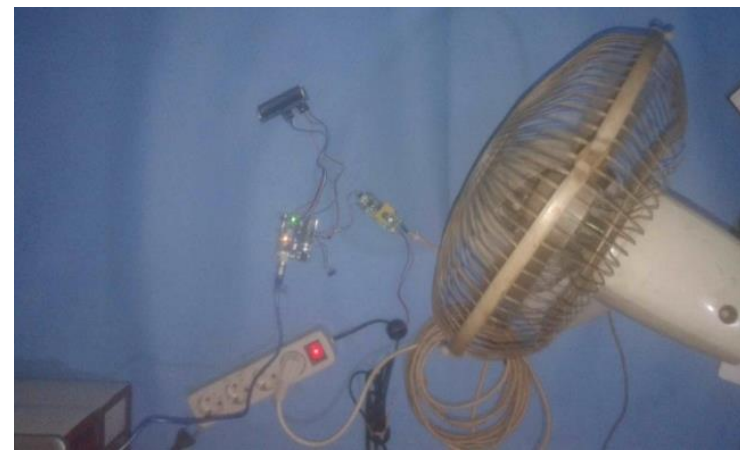

Gambar 13. Sistem Terhubung Beban Fan

Setelah beban kipas angin dinyalakan, modul cost power metering akan mengukur tegangan dan arus pemakaian dimana selanjutnya akan dihitung berapa energi yang digunakan dan berapa rupiah biaya energi yang digunkan sesuai dengan tarif dasar listrik PLN untuk golongan rumah tangga non subsidi.

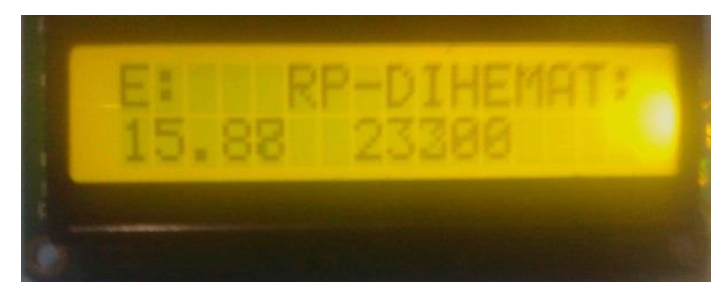

Gambar 14. Tampilan Hasil Pengukuran Energi dan Biaya

Hasil pengukuran daya dari modul pengukur daya akan diolah dan dihitung oleh Arduino. Diman selanjutnya akan ditampilkan pada LCD sebagai energi (E) dan rupiah yang dihemat (ekivalen dengan biaya pemakaian daya) karena menggunakan listrik dari solar sel seperti yang ditampilan pada gambar 14 .

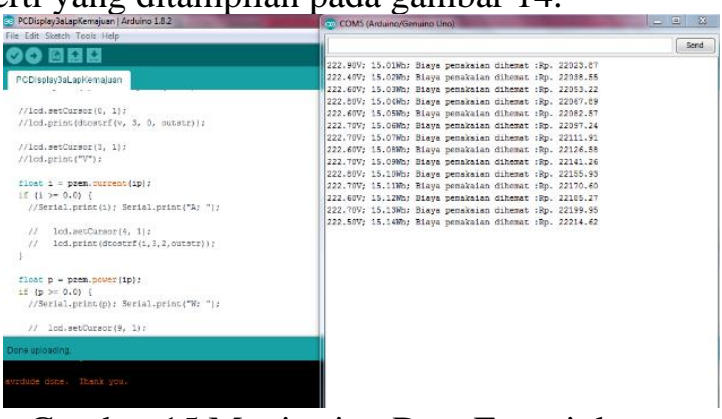

Gambar 15 Monitoring Data Energi dan Biaya Melalui Serial Port

Monitoring waktu nyata dapat juga dilakukan melalui port serial seperti pada gambar 15. Dimana port serial USB arduino dihubungkan dengan port serial USB komputer. Fasilitas ini dapat dimanfaatkan untuk penelitian lebih lanjut dalam pengembangan monitoring banyak sistem cost power metering.

\section{PENUTUP}

Dari penelitian ini telah berhasil dibangun purwarupa power metering dengan fitur pengukuran dan estimasi biaya daya terpakai untuk aplikasi Solar - Grid Hybrid Power System. Pengujian yang dilakukan berhasil melakukan pengukuran tegangan, arus, daya, energi, dan biaya listrik terpakai di laboratorium elektronika

Sejauh ini pengujian sistem hanya 
dilakukan di dalam laboratorium dan ke depan perlu dilakukan uji coba lapangan di rumah tinggal sebenarnya untuk mengetahui performansi sistem diharapkan sistem yang dapat menampilkan biaya yang dihemat dengan menggunakan sistem solar grid hybrid dapat mendorong warga membangun solar home system sendiri. Perlunya diseminasi hasil penelitian ini baik dalam bentuk karya ilmiah, atikel populer, atau sosialisasi.

\section{DAFTAR PUSTAKA}

[1] Dewan Energi Nasional, 2014, Ketahanan Energi Indonesia 2014. Jakarta, hal 52.

[2] Thomas Ackermann, Göran Andersson, Lennart Söder, 2001, Distributed generation: a definition. Electric Power Systems Research, Vol. 57, Issue 3: 195204.

[3]

en.wikipedia.org/wiki/Photovoltaic_sy stem, 2018, Photovoltaic System, diakses 1 Maret 2018

[4] www.homepower.com/articles/solarelectricity/basics/what-solar-electricity, 2018. What is Solar Electricity, diakses 1 Maret 2018.

[5] www.home-energy-metering.com/solarpower-panels.html, 2018, Metering Solar Power Panel, diakses 1 Maret 20187 